\title{
Purification and biochemical characterization of a fibrin(ogen)olytic metalloprotease from Macrovipera mauritanica snake venom which induces vascular permeability
}

\author{
EUN HEE LEE, JUNG EUN PARK, JONG WOO PARK and JUNG SUP LEE \\ Department of Biomedical Science and BK21-Plus Research Team for Bioactive Control Technology, \\ College of Natural Sciences, Chosun University, Gwangju 501-759, Republic of Korea
}

Received April 8, 2014; Accepted July 21, 2014

DOI: $10.3892 /$ ijmm.2014.1864

\begin{abstract}
In the present study, a novel fibrin(ogen)olytic metalloprotease from Macrovipera mauritanica snake venom was purified and characterized in terms of enzyme kinetics and substrate specificity. The purified enzyme [termed snake venom metalloprotease-Macrovipera mauritanica (SVMP-MM)] was composed of a single polypeptide with an apparent molecular weight of $27 \mathrm{kDa}$, as shown by sodium dodecyl sulfate-polyacrylamide gel electrophoresis. The $\mathrm{N}$-terminus of the enzyme was composed of $\mathrm{NH}_{2}$-QRFAPRYIEL-COOH, as determined by $\mathrm{N}$-terminal sequencing. The $\mathrm{A} \alpha$ - and the $\mathrm{B} \beta$-chains of fibrinogen were completely cleaved by SVMP-MM within 20 and $480 \mathrm{~min}$, respectively. However, the $\gamma$-chain was much more resistant to digestion by the enzyme. The enzyme also exhibited proteolytic activity, cleaving the $\alpha$ - $\alpha$ polymer of crosslinked fibrin, but did not effectively digest the $\gamma-\gamma$ polymer. To determine the kinetic parameters for SVMP-MM, a fluorescence-quenching peptide (termed $o$-aminobenzoic acid-HTEKLVTS-2,4-dinitrophenyl- $\mathrm{NH}_{2}$ ) containing a K-L
\end{abstract}

Correspondence to: Professor Jung Sup Lee, Department of Biomedical Science, College of Natural Sciences, Chosun University, 309 Pilmun-daero, Dong-gu, Gwangju 501-759, Republic of Korea E-mail: jsplee@chosun.ac.kr

Abbreviations: 1,10-PT, 1,10-phenanthroline; Abz, o-aminobenzoic acid; CAPS, 3-(cyclohexylamino)-1-propanesulfonic acid; DMF, dimethylformamide; Dnp, 2,4-dinitrophenyl; DTT, dithiothreitol; EDTA, ethylenediaminetetraacetic acid; FV, factor V; EGTA, glycolbis-(2-aminoethylether)-N,N,N',N'-tetraacetic acid; $\mathrm{FX}$, factor $\mathrm{X}$; FXIIIa, factor XIIIa; PBS, phosphate-buffered saline; PMSF, phenylmethanesulfonyl fluoride; $p \mathrm{NA}$, para-nitroaniline; PVDF, polyvinylidene fluoride; SDS-PAGE, sodium dodecyl sulfatepolyacrylamide gel electrophoresis; serpin, serine proteinase inhibitors; TEMED, tetramethylethylenediamine; TLCK, tosyl-lysine chloromethyl ketone; TPCK, tosyl-phenylalanyl chloromethyl ketone; XL-fibrin, cross-linked fibrin.

Key words: snake venom, Macrovipera mauritanica, metalloprotease, snake venom metalloprotease-MM, fibrin(ogen)olytic enzyme, vascular permeability sequence for SVMP-MM cleavage was designed and synthesized. The optimal $\mathrm{pH}$ and temperature for the enzyme activity were found to be 5.5 and $37^{\circ} \mathrm{C}$, respectively, when the fluorogenic substrate was synthesized and used as a substrate. Among the various divalent cations tested, $\mathrm{Ni}^{2+}$ and $\mathrm{Cu}^{2+}$ showed strong inhibitory effects on enzyme activity, with an average of $69.6 \%$ inhibition. The enzyme activity was also inhibited by treatment with 1,10-phenanthroline, ethylenediaminetetraacetic acid and glycol-bis-(2-aminoethylether)-N,N,N',N'-tetraacetic acid, but not with aprotinin, tosyl-lysine chloromethyl ketone and tosyl-phenylalanyl chloromethyl ketone, suggesting that SVMP-MM is a metalloprotease and not a serine protease. The enzymatic parameters, including the $K_{\mathrm{M}}, k_{\text {cat }}$, and $k_{\text {cat }} / K_{\mathrm{M}}$ values were estimated to be $0.015 \mathrm{mM}, 0.031 \mathrm{sec}^{-1}$, and $20.67 \mathrm{mM}^{-1} \mathrm{sec}^{-1}$, respectively. SVMP-MM induced vascular permeability by digesting type IV collagen. The results obtained in our study demonstrate that SVMP-MM is a fibrin(ogen)olytic P-I class metalloprotease, which can induce a hemorrhagic reaction in vivo.

\section{Introduction}

Snake venom contains a variety of enzymes and peptides that help the snake to overpower, kill, and/or digest its prey (1-3). As a result, envenomation following a snake bite evokes serious consequences, including systemic bleeding, myolysis, coagulopathy, hypovolemia, hemodynamic shock and acute renal failure, which are accompanied by a series of systemic deleterious effects in animals $(1,2,4,5)$. Among the snake venom components, a variety of proteolytic enzymes are directly or indirectly involved in evoking the symptoms as preliminary factors $(1,3,4)$. Proteases are basically classified into snake venom serine proteases (SVSPs) and snake venom metalloproteases (SVMPs), depending on their sensitivity to inhibitors $(3,5)$.

Recent proteomic analyses of snake venom have demonstrated that SVMPs are the major components in venom and constitute $11 \%$ to $>65 \%$ of the total venom protein contents (6). In fact, SVMPs are directly involved in the induction of local and systemic hemorrhaging (1,7). The proteases degrade the components of basement membranes underlying capillary endothelial cells (8). Thus, they trigger the disruption of the blood vessel wall and eventually evoke the release of the blood 
contents into the stroma $(1,7)$. Studies have indicated that some SVMPs have fibrin(ogen)olytic activity $(6,9)$, while others serve as prothrombin activators (10) or inactivators against blood serpins (11), demonstrating that the enzymes play pleiotropic roles in the disturbance of the hemostatic system and the induction of the leakage of blood components (6).

Macrovipera mauritanica (M. mauritanica; common name, Moorish viper) is a venomous viper found in northwestern Africa and one of four species comprising the genus Macrovipera, together with $M$. deserti, M. lebetina and M. schweizeri (12). To date, however, a little is known about the proteases in their venom. As regards the $M$. deserti and $M$. lebetina, to the best of our knowledge, there are only two studies availabe which have examined their venom; one study examined the hemorrhagic, necrotizing and inflammatoryedematogenic activity (13), and the other surveyed para-specific neutralization against the venom using a polyvalent serum (14). $M$. lebetina venom, however, has been relatively well documented (15-17). The venom contains several SVSPs, such as $\beta$-F-genase and factor V (FV) activator, and also has SVMPs, including lebetases and factor $\mathrm{X}(\mathrm{FX})$ activator $(5,18)$. The SVSPs and SVMPs all affect blood coagulation and hemostasis $(4,15)$. In the case of M. mauritanica, to the best of our knowledge, there is no study available to date demonstrating any fibrin(ogen)ase(s) that are possibly contained in its venom.

SVMPs are classified as $\alpha$ - and $\beta$-fibrin(ogen)ases, according to their proteolytic preference toward the $\mathrm{A} \alpha$ - or $\mathrm{B} \beta$-chain of fibrin(ogen) (19). Although they can cleave fibrinogen actively, they cannot induce the release of fibrinopeptides or fibrin clot formation as thrombin does (20). In contrast to SVMPs, fibrin(ogen)olytic serine proteases favorably cleave the $\mathrm{B} \beta$-chain with lower activity to the A $\alpha$-chain and generally do not cleave the $\gamma$-chain $(15,18)$.

In this study, a novel fibrin(ogen)olytic metalloprotease termed SVMP-M. mauritanica (SVMP-MM), was purified and characterized from the M. mauritanica snake venom. We describe the purification and characterization of the enzyme, with focus on its biochemical properties in terms of enzyme kinetics and substrate specificity toward a fluorogenic peptide (newly designed and synthesized in this study) and various blood coagulation-associated proteins, including plasminogen, fibrinogen and cross-linked (XL) fibrin. We also describe the effects of SVMP-MM on the induction of vascular permeability in vivo.

\section{Materials and methods}

Materials. Lyophilized M. mauritanica snake venom was purchased from Latoxan (Valence, France). All chromatographic columns, including Superdex 75 10/300 GL, Source 15Q 4.6/100 PE and Mono Q HR 5/5 were obtained from Amersham Biosciences Biotech Co. (Uppsala, Sweden). The PD-10 column was from Amersham Pharmacia Biotech Inc. (Uppsala, Sweden). Protein molecular weight markers were obtained from Fermentas (St. Leon-Rot, Germany). Human fibrinogen, $\alpha$-thrombin, factor XIIIa (FXIIIa), glycol-bis-(2-aminoethylether)N,N,N',N'-tetraacetic acid (EGTA), ethylenediaminetetraacetic acid (EDTA), 1,10-phenanthroline (1,10-PT,) N,N'-methylenebis-acrylamide, phenylmethanesulfonyl fluoride (PMSF), tetramethylethylenediamine (TEMED), Trizma base, and other chemicals were purchased from Sigma (St. Louis, MO, USA). Polyvinylidene fluoride (PVDF) membranes were obtained from Bio-Rad (Hercules, CA, USA). Synthetic chromogenic substrates, such as Boc-LGR-para-nitroaniline ( $p \mathrm{NA}$ ) (typical substrate for FXa) and Boc-VPR- $p$ NA (for thrombin) were from Seikagaku (Tokyo, Japan). Other chromogenic substrates, including H-D-VLK- $p$ NA (S-2251 for plasmin), H-D-IPR- $p$ NA (S-2288 for tPA), pyro-EGR- $p$ NA (S-2444 for urokinase), MeO-Suc-RPY- $p$ NA (S-2586 for chymotrypsin) and N- $\alpha-Z-D-R G R-p N A$ (S-2765 for FXa) were from Chromogenix (Milan, Italy). A fluorogenic peptide substrate $[o$-aminobenzoic acid (Abz)-HTEKLVTS-2,4-dinitrophenyl (Dnp)- $\mathrm{NH}_{2}$ for SVMP-MM] was synthesized by GenScript (Piscataway, NJ, USA). KC1 coagulometer was purchased from Sigma.

Purification of protease from snake venom. The lyophilized snake venom powder $(121.8 \mathrm{mg})$ was dissolved in $1.5 \mathrm{ml}$ of a standard buffer (20 mM sodium acetate, $\mathrm{pH} 5.5,100 \mathrm{mM} \mathrm{NaCl}$ ). To remove the insoluble materials, the crude venom solution was centrifuged at 9,000 $\mathrm{x}$ g for $5 \mathrm{~min}$ and the resulting precipitate was discarded. The proteins (total $40.6 \mathrm{mg}$ ) contained in the supernatant were applied onto a Superdex 75 10/300 GL column equilibrated with standard buffer and then eluted with the same buffer at a flow rate of $0.5 \mathrm{ml} / \mathrm{min}$. The active fractions were pooled and applied to a Source 15Q 4.6/100 PE column equilibrated with the same buffer. The bound proteins were eluted with a $\mathrm{NaCl}$ linear gradient ranging from 0 to $400 \mathrm{mM}$ at a flow rate of $1.0 \mathrm{ml} / \mathrm{min}$. The active fractions were pooled and desalted on a PD-10 column equilibrated with standard buffer. The desalted proteins were then loaded onto a Mono Q HR 5/5 column equilibrated with the same buffer. The bound proteins were eluted with a $\mathrm{NaCl}$ linear gradient ranging from 0 to $200 \mathrm{mM}$ at a flow rate of $0.5 \mathrm{ml} / \mathrm{min}$. The active fractions were pooled, desalted, concentrated and stored at $-70^{\circ} \mathrm{C}$ as purified enzyme. In each purification step, protein concentrations were determined using Bradford reagent (Sigma). In addition, the fibrinogenolytic activity contained in each faction was determined by fibrinogen clotting time (FCT) assay, slightly modified from the original thrombin clotting time (TCT) method (21). For the assay, $50 \mu \mathrm{l}$ of thrombin $(2.5 \mathrm{U} / \mathrm{ml})$ pre-incubated at $37^{\circ} \mathrm{C}$ for $5 \mathrm{~min}$ were mixed with $100 \mu \mathrm{l}$ of $5 \%$ fibrinogen, followed by the addition of various concentrations of protein samples to be tested with or without $1 \mathrm{mM}$ EDTA. The clotting time was monitored using a $\mathrm{KCl}$ coagulometer. Protease activity was also examined using azocasein assay as previously described (22).

Proteolytic activity assay with a fluorogenic peptide substrate. The fluorogenic peptide substrate (termed Abz-HTEKLVTSDnp- $\mathrm{NH}_{2}$ ) dissolved in $30 \%$ dimethylformamide (DMF) was resuspended in standard reaction buffer $(20 \mathrm{mM}$ sodium acetate, $\mathrm{pH} 5.5,100 \mathrm{mM} \mathrm{NaCl}$ ) at a final concentration of $80 \mu \mathrm{M}$ and incubated at $37^{\circ} \mathrm{C}$ during which the increase in fluorescence was monitored at $\lambda_{\mathrm{ex}}=320 \mathrm{~nm}$ and $\lambda_{\mathrm{em}}=420 \mathrm{~nm}$ for 15 min using a spectrofluorometer (Molecular Devices Corp., Sunnyvale, CA, USA).

Sodium dodecyl sulfate-polyacrylamide gel electrophoresis (SDS-PAGE). SDS-PAGE was performed according to the method of Laemmli (23). Protein samples to be analyzed were 
mixed with an equal volume of $2 \mathrm{X}$ SDS-PAGE sample buffer, boiled at $100^{\circ} \mathrm{C}$ for $3 \mathrm{~min}$ and then loaded onto 8,10 or $12 \%$ gels. Following electrophoresis, the protein bands were visualized by staining the gel with Coomassie brilliant blue. Protein molecular weight markers used for SDS-PAGE were as follows: $\beta$-galactosidase $(116 \mathrm{kDa})$, bovine serum albumin $(66 \mathrm{kDa})$, ovalbumin (45 kDa), lactate dehydrogenase $(35 \mathrm{kDa})$, restriction enzyme $B s p 981(25 \mathrm{kDa}), \beta$-lactoglobulin $(18.4 \mathrm{kDa})$ and lysozyme $(14.4 \mathrm{kDa})$.

Fibrinogen cleavage assay. To examine the fibrinogenolytic activity of the purified enzyme, human fibrinogen $(3.47 \mathrm{mg} / \mathrm{ml})$ was dissolved in standard reaction buffer and incubated with SVMP-MM enzyme $(5.5 \mathrm{mg} / \mathrm{ml})$ at $37^{\circ} \mathrm{C}$ at a final volume of $140 \mu 1$, in which the molar ratio of enzyme vs. fibrinogen was 1:50. From the reaction mixture, $15 \mu \mathrm{l}$ each of aliquots was withdrawn at various time periods and the reaction was terminated by the addition of $3 \mu \mathrm{l}$ of $6 \mathrm{X}$ SDS-PAGE sample buffer. The samples were then boiled for $3 \mathrm{~min}$ and the resulting products were analyzed by SDS-PAGE as previously described $(22,24)$.

Turbidity assay for the spontaneous polymerization of fibrin monomers. The spontaneous polymerization of fibrin monomers generated from fibrinogen by thrombin or SVMP-MM cleavage was examined by measuring the increase in turbidity as previously described (22). Typically, $90 \mu \mathrm{g}$ of fibrinogen dissolved in standard reaction buffer were mixed with 0.02 units of thrombin, 0.04 units of plasmin or SVMP-MM enzyme ( 3 or $6 \mu \mathrm{g}$ ) at $37^{\circ} \mathrm{C}$ and the increase in the absorbance at $350 \mathrm{~nm}$ was then recorded using a 96-well plate reader (Molecular Devices Corp.). The fibrinolytic activity of plasmin or SVMP-MM was determined by measuring the decrease in turbidity of XL-fibrin. Typically $90 \mu \mathrm{l}$ of $1 \mathrm{mg} / \mathrm{ml}$ fibrinogen in standard reaction buffer were added to $10 \mu \mathrm{l}$ of thrombin $(17.7 \mathrm{U} / \mathrm{ml})$ and pre-incubated for $1 \mathrm{~h}$ at $25^{\circ} \mathrm{C}$ to allow the formation of fibrin polymer. Thereafter, $10 \mu \mathrm{l}$ of SVMP-MM enzyme (3 or $6 \mu \mathrm{g}$ ) or plasmin $(0.04$ or 0.08 units) were added and further incubated for $2 \mathrm{~h}$ at $37^{\circ} \mathrm{C}$. The increase or decrease in absorbance at $350 \mathrm{~nm}$ was then recorded with a 96-well plate reader.

Analysis of the N-terminal sequence of the purified enzyme. The purified enzyme was subjected to electrophoresis on $12 \%$ SDS-polyacrylamide gel and transferred onto a PVDF membrane in $10 \mathrm{mM}$ 3-(cyclohexylamino)-1-propanesulfonic acid (CAPS) buffer ( $\mathrm{pH} 11$ ) containing $10 \%$ methanol. The blot was stained with Coomassie brilliant blue, followed by destaining as previously described (24). A target band was excised from the membrane and subjected to N-terminal sequencing with a Precise 491 HT protein sequencer (Applied Biosystems, Foster City, CA, USA). The sequencing was performed by the Korea Basic Research Institute (Daejun, Korea).

Type IV collagen digestion. Type IV collagen $(0.16 \mathrm{mg} / \mathrm{ml})$ was incubated with SVMP-MM $(40 \mu \mathrm{g} / \mathrm{ml})$ in $200 \mu \mathrm{l}$ of the standard reaction buffer at $37^{\circ} \mathrm{C}$. At various time intervals, $30 \mu \mathrm{l}$ each of aliquots was withdrawn and mixed with $6 \mu 1$ of $6 \mathrm{X}$ SDS-PAGE sample buffer. The samples were boiled for $3 \mathrm{~min}$ and the proteins were then electrophoresed on $8 \%$ polyacrylamide gel, followed by staining the gel with Coomassie brilliant blue.
Effects of various protease inhibitors, divalent ions, $p H$ and temperature on enzyme activity. To examine the effects of various inhibitors [EDTA, EGTA, dithiothreitol (DTT), tosyl-lysine chloromethyl ketone (TLCK), tosyl-phenylalanyl chloromethyl ketone (TPCK), 1,10-PT, bestatin, aprotinin and PMSF] or divalent ions $\left(\mathrm{Ca}^{2+}, \mathrm{Cu}^{2+}, \mathrm{Fe}^{2+}, \mathrm{Mg}^{2+}, \mathrm{Mn}^{2+}, \mathrm{Ni}^{2+}\right.$ and $\mathrm{Zn}^{2+}$ ) on enzyme activity, reaction mixtures were composed of $3 \mu \mathrm{g}$ of purified enzyme, $1 \mathrm{mM}$ of corresponding additive and $80 \mu \mathrm{M}$ of a fluorogenic peptide (Abz-HTEKLVTS-Dnp- $\mathrm{NH}_{2}$ ) as a substrate in standard reaction buffer and incubated for $15 \mathrm{~min}$ at $37^{\circ} \mathrm{C}$. The effects of temperature on enzyme activity were also assayed at different temperatures under the conditions described above. The $\mathrm{pH}$ dependency of the enzyme was also examined at $37^{\circ} \mathrm{C}$ under different buffer systems with the same concentrations of enzyme and fluorogenic peptide substrate. The buffer systems used for the $\mathrm{pH}$ requirements of the enzyme were as follows: $50 \mathrm{mM}$ sodium acetate $(\mathrm{pH} 4.0-5.5)$; $50 \mathrm{mM}$ potassium phosphate $(\mathrm{pH} 6.0-7.5) ; 50 \mathrm{mM}$ Tris- $\mathrm{HCl}$ (pH 8.0-8.5); $50 \mathrm{mM}$ glycine- $\mathrm{NaOH}$ (pH 9.0-10.5). In all cases, the reactions were triggered by the addition of $80 \mu \mathrm{M}$ of the fluorogenic peptide and the relative fluorescence units (RFUs) were monitored at $\lambda_{\mathrm{ex}}=320 \mathrm{~nm}$ and $\lambda_{\mathrm{em}}=420 \mathrm{~nm}$ for $15 \mathrm{~min}$ using a spectrofluorometer.

Vascular permeability assay. Vascular permeability induced by the enzyme was examined by a modification of the Miles assay (25). Evans blue dye solution was freshly prepared in $0.6 \%$ phosphate-buffered saline (PBS) at a final concentration of $5 \%$ and filtered through a paper $(0.2 \mu \mathrm{m}$ in pore size) before use. A guinea pig (300 g in body weight, male) was lightly anesthetized with diethyl ether, and the dye $(65 \mathrm{mg} / \mathrm{kg}$ body weight) was administered intravenously, followed by the intradermal injection of $10 \mu \mathrm{g}$ of SVMP-MM (dissolved in PBS) at the back of the animal. After $10 \mathrm{~min}$, the guinea pigs were euthanized by urethane overdose and photographed to visualize the dye leakage. For the quantification of the dye leakage, the back skin around the injection spot (approximately $1 \mathrm{~cm}^{2}$ ) was cut out, soaked in $3 \mathrm{ml}$ of formamide, and incubated for $48 \mathrm{~h}$ at $60^{\circ} \mathrm{C}$ to allow the release of the dye. The amount of dye exclusion was determined by measuring the absorbance at $620 \mathrm{~nm}$ and expressed as a measure in micrograms of Evans blue dye efflux, as previously described (25). All efforts were made to minimize animal suffering and to reduce the number of animals used. All experimental procedures were performed in accordance with the NIH Guide for the Care and Use of Laboratory Animals (NIH publication no. 80-23, 1996.)

\section{Results}

Purification of a fibrin(ogen)olytic enzyme from M. mauritanica snake venom. A fibrin(ogen)olytic metalloprotease was purified by three chromatographic steps, using a size exclusion and two ion exchanger columns in order. For the purification, the crude venom powder of $M$. mauritanica $(121.8 \mathrm{mg}$ ) was dissolved in standard buffer and centrifuged for $5 \mathrm{~min}$ at $9,000 \mathrm{x} g$ to remove insoluble materials. The soluble proteins (total $40.6 \mathrm{mg}$ ) obtained were then fractionated by a size exclusion chromatography using a Superdex 75 10/300 GL column, from which the proteins were eluted at a flow rate of $0.5 \mathrm{ml} / \mathrm{min}$ (Fig. 1A). As shown in the elution profile of Fig. 1A, the proteins 
Table I. Summary of the purification process for the SVMP-MM protease from M. mauritanica snake venom.

\begin{tabular}{lcccc}
\hline Purification step & Total protein $(\mathrm{mg})$ & Total activity $(\mathrm{U})^{\mathrm{a}}$ & Specific activity $(\mathrm{U} / \mathrm{mg})$ & ${\text { Yield }(\%)^{\mathrm{b}}}^{\mathrm{a}}$ \\
\hline Crude venom & 121.8 & 19,500 & 160 & 100 \\
Superdex 75 & 16.8 & 12,800 & 762 & 13.8 \\
Source Q & 4.2 & 3,360 & 800 & 3.5 \\
Mono Q & 2.8 & 2,800 & 1,000 & 2.3 \\
\hline
\end{tabular}

${ }^{\mathrm{a} O n e}$ unit $(\mathrm{U})$ was defined as the amount of the enzyme digesting $80 \mu \mathrm{M}$ of fluorogenic peptide substrate termed Abz-HTEKLVTS-Dnp-NH ${ }_{2}$ for $10 \mathrm{~min} .{ }^{b}$ Total protein in the crude snake venom was assigned the value of $100 \%$. SVMP, snake venom metalloproteases; Abz, $o$-aminobenzoic acid; Dnp, 2,4-dinitrophenyl.

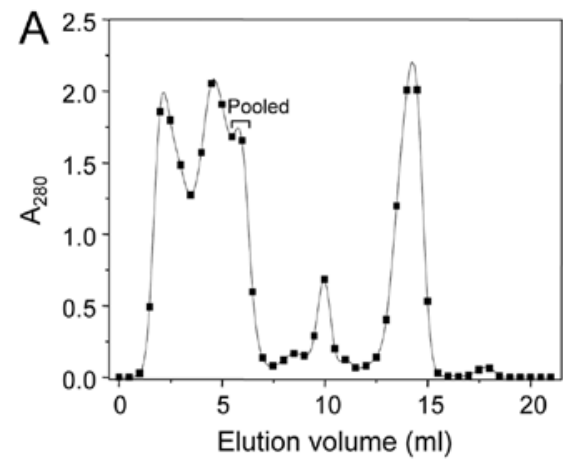

C

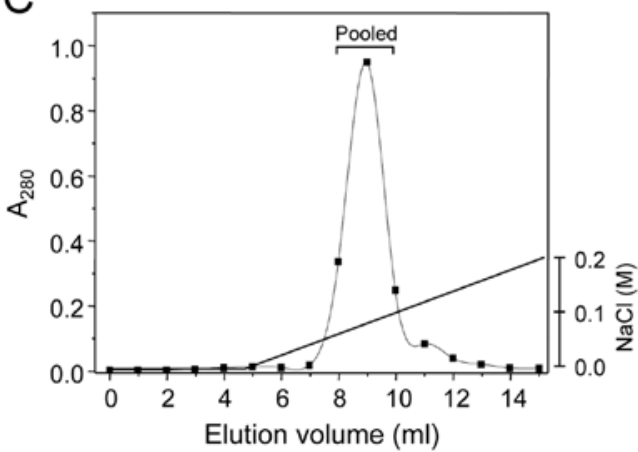

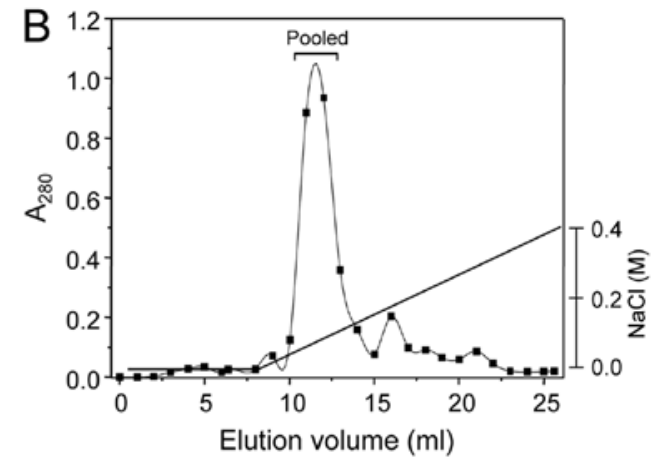

$\mathrm{D}$

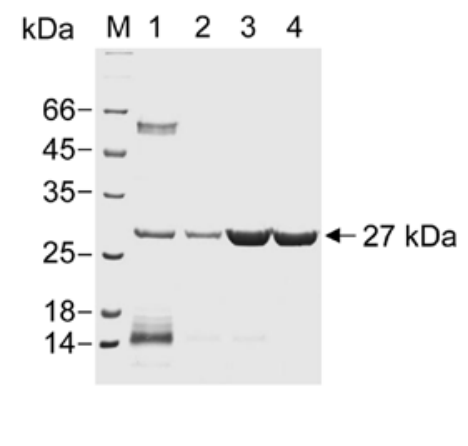

Figure 1. Purification of snake venom metalloprotease (SVMP) enzyme from M. mauritanica snake venom (SVMP-MM) using 3 chromatographic steps. (A) Size-exclusion chromatography. Crude snake venom $(121.8 \mathrm{mg})$ was dissolved in standard buffer and the insoluble materials were removed by centrifugation for $5 \mathrm{~min}$ at $9,000 \mathrm{x}$. The resulting supernatant (total $40.6 \mathrm{mg}$ of protein) was loaded on a Superdex 75 column and the proteins were eluted at a flow rate of $0.5 \mathrm{ml} / \mathrm{min}$. Active fractions were pooled as indicated by the bracket. (B) Source Q column chromatography. The fractions pooled from the Superdex 75 column chromatography were applied to a Source column and the bound proteins were eluted with a $\mathrm{NaCl}$ linear gradient of 0 to $400 \mathrm{M}$ at flow rate of $1.0 \mathrm{ml} / \mathrm{min}$. Active fractions were pooled as indicated by the bracket. (C) Mono Q column chromatography. Proteins collected from the Source Q column chromatography were applied to an anion exchanger Mono Q column and the proteins bound were eluted by a $\mathrm{NaCl}$ linear gradient of 0 to $200 \mathrm{mM}$ at flow rate of $0.5 \mathrm{ml} / \mathrm{min}$. In each chromatographic step, protein elution was monitored by measuring the absorbance at $280 \mathrm{~nm}$. (D) SDS-PAGE of proteins obtained from each purification step. The proteins collected were electrophoresed on a $12 \%$ SDS-polyacrylamide gel and stained with Coomassie brilliant blue. In each purification step, the fibrinogenolytic activity contained in each fraction was examined with fibrinogen clotting time (FCT) assay as described in Materials and methods. Lane M, protein molecular weight size makers; lane 1, crude snake venom; lane 2, proteins from Superdex 75 column; lane 3, proteins from Source Q column; lane 4, proteins from Mono Q column.

were separated into at least 5 peaks according to their sizes, among which the third one (12 to 14 in the elution volumes) showed fibrinogenolytic activity, as judged by FCT assay. From this column chromatography, a total of $16.8 \mathrm{mg}$ proteins were obtained by pooling the 3 active fractions (Table I). The proteins acquired were further separated by an anion exchanger column chromatography on a Source 15Q 4.6/100 PE column (Fig. 1B). In this chromatography, the proteins bound were eluted with a $\mathrm{NaCl}$ linear gradient of 0 to $400 \mathrm{mM}$ at a flow rate of $1.0 \mathrm{ml} / \mathrm{min}$, from which 3 active fractions (10 to 12 in the elution volumes) were pooled to acquire a total of $4.2 \mathrm{mg}$ proteins (Fig. 1B and Table I). Thereafter, the proteins obtained were lastly applied and fractionated by another anion exchanger Mono Q HR 5/5 column chromatography. The proteins bound were eluted with a $\mathrm{NaCl}$ linear gradient ranging from 0 to $200 \mathrm{mM}$ at flow rate of $0.5 \mathrm{ml} / \mathrm{min}$, and 4 active fractions ( 7 to 10 in the elution volumes) were pooled (Fig. 1C). From this last chromatography, a total $2.8 \mathrm{mg}$ of proteins could be obtained as a purified enzyme (Table I). The purified enzyme was designated to SVMP-MM. Table I summarizes the puri- 
Table II. Comparison of the N-terminal amino acid sequence of SVMP-MM with those of several snake venom proteases.

\begin{tabular}{|c|c|c|c|c|c|}
\hline Snake species & Enzyme & N-terminal sequence ${ }^{a}$ & Identity (\%) & Position of sequence & Accession no. \\
\hline M. mauntanica & SVMP-MM & --QREAPRYIEL & 100 & $1-10$ & This study \\
\hline B. asper & BAP1 & --ERESP-YIEL & 77.8 & $192-202$ & P83512 \\
\hline M. lebetina & Lebetase-II & --QREEPRYIEL & 90.0 & $195-205$ & Q98995 \\
\hline M. lebetina & Lebetase-4 & -QQREDPRYIEL & 90.0 & $15-25$ & Q3ZD74 \\
\hline M. lebitina & VIF & --EREAPRYIEL & 90.0 & $1-10$ & P83255 \\
\hline B. moojeni & BmooMP $\alpha-\mathrm{I}$ & $---R E \mathbf{S P}-\mathbf{H I E L}$ & 75.0 & $1-8$ & 3GBO_A \\
\hline B. neuwiedi & Neuwiedase & QQRF F PQRYIEL & 60.0 & $1-12$ & Q9I9R4 \\
\hline
\end{tabular}

${ }^{a} \mathrm{~N}$-terminal sequences located in fully processed proteases. Amino acid residues different from those of the SVMP-MM sequence are written in bold. The character '-' denotes the absence of an amino acid. SVMP, snake venom metalloprotease.

fication results. The specific activity of purified enzyme was $1,000 \mathrm{U} / \mathrm{mg}$ proteins and approximately $2.8 \mathrm{mg}$ of enzymes were obtained in homogeneity, with $2.3 \%$ in yield (Table I) .

Estimation of molecular weight and N-terminal amino acid sequence of SVMP-MM. The purified SVMP-MM enzyme appeared as single bands on an SDS-polyacrylamide gel stained with Coomassie brilliant blue and the molecular mass was estimated to be $27 \mathrm{kDa}$ (Fig. 1D), a size similar to the metalloproteases, BlaH1 (28 kDa) from Bothrops lanceolatus (B. lanceolatus) (26) and VIF (26 kDa) from M. lebetina venom (27). In addition, SVMP-MM formed just one peak when it was eluted through gel filtration on a Superdex 75 10/300 GL column (data not shown). These results suggest that SVMP-MM is a monomeric protease with a small size. The N-terminus of SVMP-MM was composed of $\mathrm{NH}_{2}$-QRFAPRYIEL-COOH, as analyzed by amino acid sequencing. The comparison of amino acid sequences showed that the $\mathrm{N}$-terminal sequence of SVMP-MM was highly conserved in several metalloproteases derived from snake venoms, in which BAP1 from Bothrops asper (28), BmooMP $\alpha-\mathrm{I}$ from Bothrops moojeni (29), neuwiedase from $B$. neuwiedi (30), and 3 proteases (VIF, lebetases-II and -4) from M. lebetina $(16,27,31)$ were included and there was an average of $80.5 \%$ identity between them (Table II).

Fibrinogenolytic and fibrinolytic activities of SVMP-MM. Various plasma proteins, including fibrinogen, plasminogen and prothrombin, which are involved in blood coagulation and hemostasis, were digested by the SVMP-MM enzyme (data not shown). However, there were no detectable plasmin and thrombin activities when the plasminogen and prothrombin were incubated with SVMP-MM in the presence of S-2251 (typical substrate for plasmin) and Boc-VPR-pNA (for thrombin) (data not shown). These results suggest that SVMP-MM can neither activate plasminogen nor prothrombin, as other SVMPs can $(6,32)$. Fibrinogen was also one of efficient protein substrates for SVMP-MM (Fig. 2). The enzyme actively digested the $\mathrm{A} \alpha$ - and the $\mathrm{B} \beta$-chains of fibrinogen to a different extent (Fig. 2A). The A $\alpha$ - and the $\mathrm{B} \beta$-chains of fibrinogen were completely degraded by the enzyme within 20 and $480 \mathrm{~min}$, respectively. However, the $\gamma$-chain was much more resistant to digestion by the enzyme, even with overnight incubation (Fig. 2A). It is well known that fibrin monomers generated from thrombin-cleaved fibrinogen can be polymerized spontaneously in the absence of FXIIIa in vitro, accompanied with an increase in turbidity as the polymerization proceeds (24). In this study, the spontaneous polymerization of fibrin monomers generated by thrombin or possibly SVMP-MM fibrinogen cleavage was examined by measuring the increase in turbidity. As expected, thrombin increased the turbidity effectively, but SVMP-MM did not. The thrombin-induced increase in turbidity was decreased by plasmin since the fibrin polymers were cleaved by the enzyme (Fig. 2B). As with plasmin, SVMP-MM decreased the thrombin-induced increase in turbidity in a dose-dependent manner. These results suggest that SVMP-MM cannot allow the fibrin monomers to be polymerized spontaneously when it cleaves fibrinogen. SVMP-MM was also able to cleave the XL-fibrin formed by thrombin in the presence of FXIIIa and fibrinogen (Fig. 2C). The enzyme showed $\alpha-\alpha$ polymer-cleaving activity, accompanied with the generation of fibrin degrading products (FDPs); however, it could not digest $\gamma-\gamma$ polymers effectively (Fig. 2C), as in the case of its fibrinogen cleavage (Fig. 2A). This XL-fibrin-cleaving activity of SVMP-MM was also examined by turbidity assay (Fig. 2D). Plasmin clearly decreased the turbidity of XL-fibrin in a dose-dependent manner, but SVMP-MM did not at the doses used. These results seem to be related to the inability of SVMP-MM in cleaving both the $\gamma$-chain of fibrinogen and the $\gamma-\gamma$ polymers of XL-fibrin (Fig. 2D). SVMP-MM inhibited the thrombin-induced clotting time in a dose-dependent manner, as judged by FCT assay (Fig. 3). The clotting time was prolonged 2.2-fold, compared to that of the untreated control; however, the delaying effect of the enzyme was diminished in the presence of $1 \mathrm{mM}$ of EDTA (Fig. 3), suggesting that SVMP-MM can delay thrombin-induced clotting time through a defibrinogenation and this is related directly to the enzyme activity. The results presented in Figs. 2 and 3 suggest that SVMP-MM belongs to the fibrin(ogen)ase family which has no clot formation activity, as it can just cleave predominantly on the $A \alpha$-chain and less on both the $B \beta$ - and the $\gamma$-chains of fibrinogen subunits $(33,34)$.

Design and synthesis of a fluorescence-quenching peptide substrate for SVMP-MM. In this study, a fluorescence-quenching peptide substrate was designed and synthesized on the basis 
A

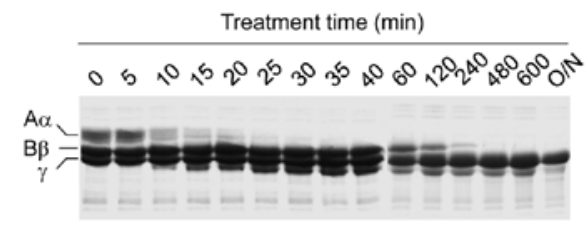

B

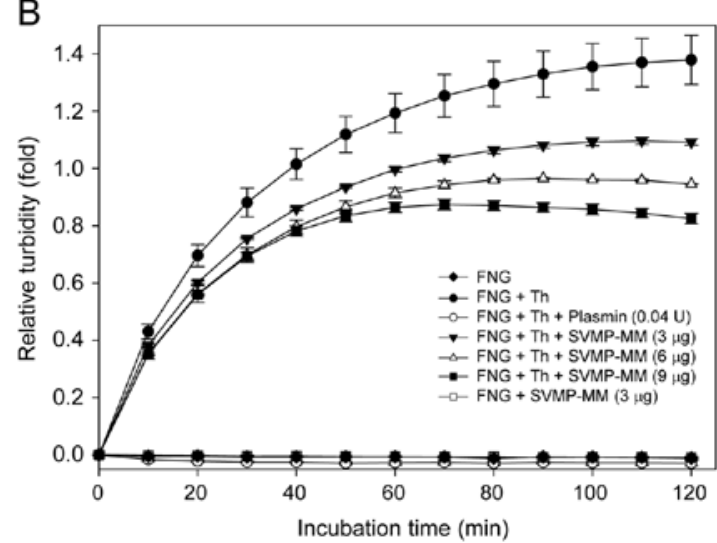

C

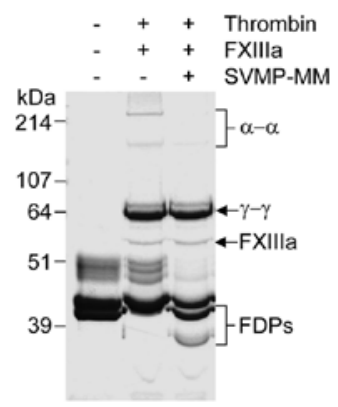

$\mathrm{D}$

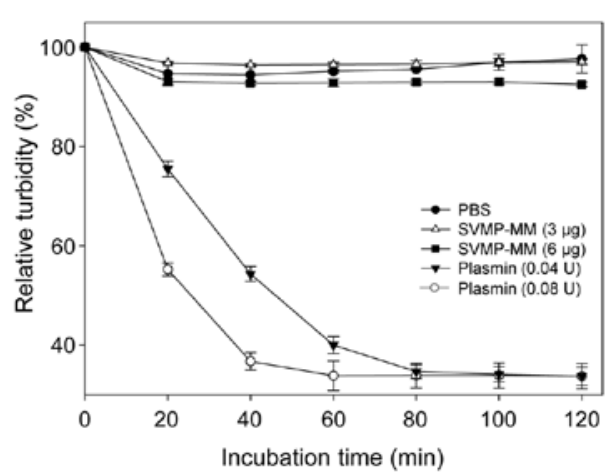

Figure 2. Fibrino(geno)lytic activity of the enzyme from snake venom metalloprotease (SVMP) enzyme from M. mauritanica snake venom (SVMP-MM). (A) Fibrinogenolytic activity assay. SVMP-MM enzyme was added to fibrinogen solution at a molar ratio of 1:50 and the reaction mixture was incubated for various time periods at $37^{\circ} \mathrm{C}$ as indicated. The reaction products were electrophoresed on $10 \%$ polyacrylamide gel and stained with Coomassie brilliant blue. The positions of $\mathrm{A} \alpha-, \mathrm{B} \beta$ - and $\gamma$-chains of fibrinogen are shown on the left side of the panel. $\mathrm{O} / \mathrm{N}$ denotes overnight incubation at $37^{\circ} \mathrm{C}$. (B) Determination of the spontaneous polymerization of fibrin monomers. Fibrinogen $(90 \mu \mathrm{g})$ dissolved in the standard reaction buffer (pH 5.5) was mixed with thrombin (0.02 units) or SVMP-MM ( 3 or $6 \mu \mathrm{g}$ ) at $37^{\circ} \mathrm{C}$. The increase in turbidity was monitored at $350 \mathrm{~nm}$ and expressed as relative activity as a percentage as described in Materials and methods. FNG, fibrinogen; Th, thrombin. (C) Fibrinolytic activity assay. The cross-linked (XL)-fibrin formed from fibrinogen (0.7 mg/ml) by thrombin $(0.13 \mathrm{U} / \mathrm{ml})$ in the presence of factor XIIIa (FXIIIa) $(0.13 \mathrm{U} / \mathrm{ml})$ and $1 \mathrm{mM} \mathrm{CaCl}_{2}$ was incubated with $2 \mu \mathrm{g}$ of SVMP-MM enzyme for $30 \mathrm{~min}$ at $37^{\circ} \mathrm{C}$. The reaction products were electrophoresed on an $8 \%$ SDS-polyacrylamide gel and stained with Coomassie brilliant blue to visualize proteins. The '+' and '-' symbols represent the addition and the omission of the corresponding additive, respectively. The positions of $\alpha-\alpha$ and $\gamma-\gamma$ chains of XL-fibrin are shown on the right side of the panel. FDPs, fibrin degrading products. (D) Determination of the fibrinolytic activity of plasmin and SVMP-MM by turbidity assay. Fibrinogen (90 $\mu \mathrm{g}$ dissolved in the standard reaction buffer, $\mathrm{pH} 5.5)$ was mixed with thrombin ( 0.18 units) and pre-incubated for $1 \mathrm{~h}$ at $25^{\circ} \mathrm{C}$ to allow the formation of fibrin polymer. SVMP-MM ( 3 or $6 \mu \mathrm{g}$ ) or plasmin ( 0.04 or 0.08 units) was then added and further incubated for $2 \mathrm{~h}$ at $37^{\circ} \mathrm{C}$, during which the decrease in absorbance at $350 \mathrm{~nm}$ was then recorded with a 96 -well plate reader.

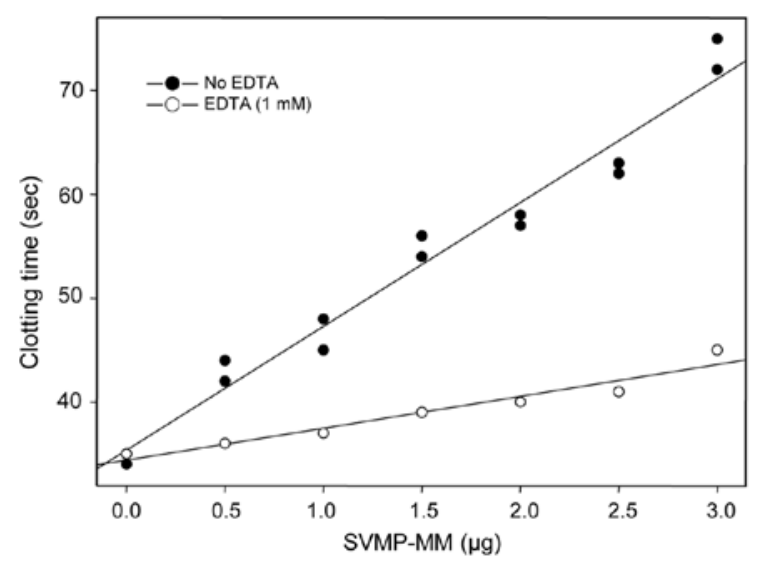

Figure 3. Fibrinogen clotting time (FCT) assay. Various concentrations of snake venom metalloprotease (SVMP) enzyme from $M$. mauritanica snake venom (SVMP-MM) were incubated with thrombin (0.125 units) and fibrinogen $(0.3 \%)$ in the absence $(\bullet)$ or presence $(O)$ of $1 \mathrm{mM}$ ethylenediaminetetraacetic acid (EDTA) for $5 \mathrm{~min}$ at $37^{\circ} \mathrm{C}$. FCT values were then monitored using a $\mathrm{KC1}$ coagulometer and expressed as clotting time in seconds (sec).

of the cleavage site of SVMP-MM on its protein substrate. To locate the cleavage site of the enzyme on the fibrinogen substrate first, $140 \mu \mathrm{g}$ of fibrinogen were digested with $1 \mu \mathrm{g}$ of enzyme for $20 \mathrm{~min}$ at $37^{\circ} \mathrm{C}$ and the peptide products generated were separated on a $12 \%$ SDS-polyacrylamide gel (Fig. 4A). Among the peptide fragments produced, a distinct $17.5 \mathrm{kDa}$ protein band was excised from the gel and its $\mathrm{N}$-terminus was sequenced. The sequencing results showed that SVMP-MM specifically cleaved the peptide bond of $\mathrm{Lys}^{413}$ and $\mathrm{Leu}^{414}$, which is located in the $\alpha$-chain of fibrinogen (35). On the basis of this result, a peptide flanked by the Abz and Dnp groups, namely, Abz-HTEKLVTS-Dnp- $\mathrm{NH}_{2}$ containing SVMP-MM cleavage site (K-L) was designed and synthesized in order to form a fluorescent donor (Abz group)-acceptor (Dnp group) pair. Therefore, Abz fluorescence would be quenched by the Dnp group (36) until the enzyme cleaves the peptide bond located between $\mathrm{K}$ and $\mathrm{L}$ residues in the synthetic peptide. The RFU clearly increased in a dose-dependent manner, when SVMP-MM (3 $\mu \mathrm{g})$ was incubated with various concentrations of the fluorogenic substrate and then the fluorescence produced was monitored for $15 \mathrm{~min}$ at $\lambda_{\mathrm{ex}}=320 \mathrm{~nm}$ and $\lambda_{\mathrm{em}}=420 \mathrm{~nm}$ (Fig. 4B). This result suggests that the fluorescence-quenching peptide synthesized may be used as a suitable substrate for elucidating the enzymatic properties of SVMP-MM. 

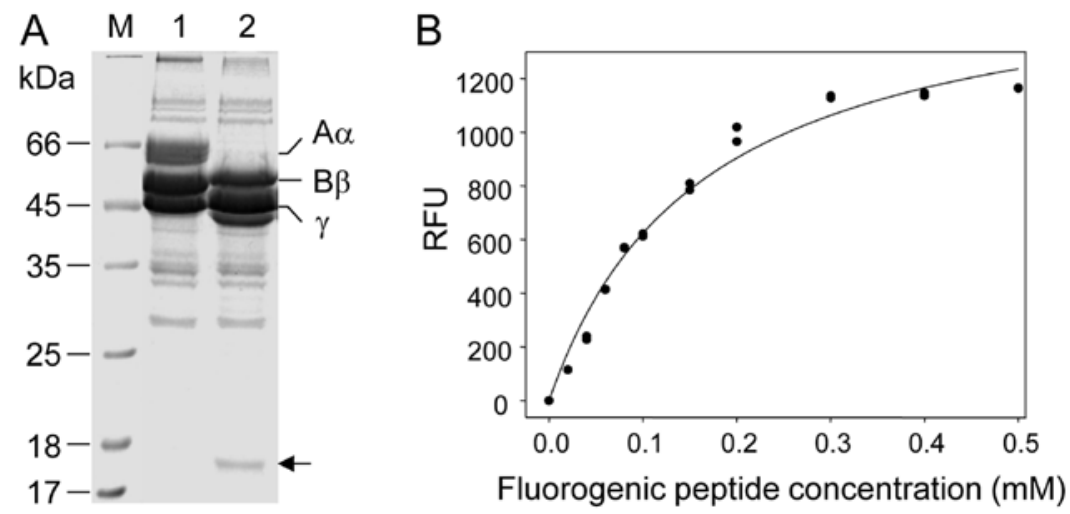

Figure 4. Cleavage site and fluorogenic activity of snake venom metalloprotease (SVMP) enzyme from M. mauritanica snake venom (SVMP-MM). (A) Fibrinogen cleavage by SVMP-MM. The enzyme $(1 \mu \mathrm{g})$ was incubated with $140 \mu \mathrm{g}$ of fibrinogen (FNG) at $37^{\circ} \mathrm{C}$ for 20 min and the products generated were then separated on $12 \%$ SDS-polyacrylamide gel, followed by staining with Coomassie brilliant blue to visualize. The positions of A $\alpha$-, B $\beta$ - and $\gamma$-chains of fibrinogen are shown on the right side of the panel. The arrow on the bottom of gel indicates a peptide fragment used for $\mathrm{N}$-terminal sequencing. M, Protein molecular weight size makers; lane 1, FNG only; lane 2, FNG plus SVMP-MM. (B) Fluorogenic activity of SVMP-MM towards $o$-aminobenzoic acid (Abz)-HTEKLVTS-2,4dinitrophenyl (Dnp)- $\mathrm{NH}_{2}$. SVMP-MM $(3 \mu \mathrm{g})$ was incubated with various concentrations of fluorogenic peptide substrate for $10 \mathrm{~min}$ at $37^{\circ} \mathrm{C}$ and the fluorescence produced was monitored for further $15 \mathrm{~min}$ at $\lambda_{\mathrm{em}}=420 \mathrm{~nm}$ and $\lambda_{\mathrm{ex}}=320 \mathrm{~nm}$. The level of fluorescence emitted was expressed as the relative fluorescence unit (RFU).

Table III. Effects of various divalent cations, protease inhibitors and chemical reagents on SVMP-MM activity.

\begin{tabular}{lcc}
\hline Additive & Concentration $(\mathrm{mM})$ & Relative activity $(\%)^{\mathrm{a}}$ \\
\hline Control & 0 & 100 \\
$\mathrm{Ca}^{2+}$ & 1 & 95.1 \\
$\mathrm{Cu}^{2+}$ & 1 & 17.6 \\
$\mathrm{Fe}^{2+}$ & 1 & 88.6 \\
$\mathrm{Mg}^{2+}$ & 1 & 98.2 \\
$\mathrm{Mn}^{2+}$ & 1 & 104.1 \\
$\mathrm{Ni}^{2+}$ & 1 & 43.2 \\
$\mathrm{Zn}^{2+}$ & 0.1 & 95.8 \\
$\mathrm{Zn}^{2+}$ & 1 & 78.5 \\
$\mathrm{TLCK}$ & 1 & 103.5 \\
TPCK & 1 & 99.7 \\
EDTA & 1 & 0 \\
$1,10-\mathrm{PT}$ & 1 & 1.2 \\
Bestatin & 0.01 & 81.6 \\
PMSF & 1 & 92.6 \\
Aprotinin & 1 & 97.9 \\
EGTA & 1 & 3.1 \\
DTT & 1 & 0 \\
\hline
\end{tabular}

${ }^{\mathrm{a}} \mathrm{A}$ synthetic fluorogenic peptide (Abz-HTEKLVTS-Dnp- $\mathrm{NH}_{2}$ ) was used for the SVMP-MM activity assay as a substrate with or without the corresponding additive at $37^{\circ} \mathrm{C}$ for $15 \mathrm{~min}$ in standard buffer as described in Materials and methods. The RFU value from the untreated control was assigned $100 \%$. SVMP, snake venom metalloprotease; RFU, relative fluorescence unit; TLCK, tosyl-lysine chloromethyl ketone; TPCK, tosylphenylalanyl chloromethyl ketone; EDTA, ethylenediaminetetraacetic acid; 1,10-PT, 1,10-phenanthroline; PMSF, phenylmethanesulfonyl fluoride; EGTA, glycol-bis(2-aminoethylether)-N,N,N',N'-tetraacetic acid.

Enzymatic properties and kinetic parameters of SVMP-MM. The optimal $\mathrm{pH}$ and temperature for SVMP-MM activity were examined with the fluorescence-quenching peptide, Abz-HTEKLVTS-Dnp- $\mathrm{NH}_{2}$, as a substrate (Fig. 5). The enzyme exhibited its optimum pH (Fig. 5A) and temperature (Fig. 5B) at 5.5 and $37^{\circ} \mathrm{C}$, respectively, with a total loss of activity under $\mathrm{pH} 10.5$ and at $4^{\circ} \mathrm{C}$. Considering the $\mathrm{pH}$, temperature and ionic strength (data not shown) for the maximal enzyme activity, a standard reaction buffer consisting of $20 \mathrm{mM}$ sodium acetate $(\mathrm{pH} 5.5)$ and $100 \mathrm{mM} \mathrm{NaCl}$ was prepared and used for further experiments. The effects of various divalent cations and protease inhibitors on SVMP-MM activity were examined (Table III). Divalent cations, such as $\mathrm{Ca}^{2+}, \mathrm{Mg}^{2+}$ and $\mathrm{Mn}^{2+}$ showed no significant stimulatory or inhibitory effects on SVMP-MM activity; however, $\mathrm{Fe}^{2+}$ and $\mathrm{Zn}^{2+}(1 \mathrm{mM})$ exhibited a slight inhibitory effect on the enzyme activity at different levels. However, a low dose of $\mathrm{Zn}^{2+}(<0.1 \mathrm{mM})$ did not show such a significant inhibitory effect on the activity (Table III). In addition, $\mathrm{Ni}^{2+}$ and $\mathrm{Cu}^{2+}$ showed relatively strong inhibitory effects on enzyme activity, with an average of $69.6 \%$ inhibition, compared to those of the untreated control. More importantly, the enzyme activity was clearly inhibited by treatment with 1,10PT, EDTA and EGTA, which are all known metalloprotease inhibitors (37). Among the metalloprotease inhibitors used, bestatin did not act as an effective inhibitor against the enzyme activity. However, TLCK, TPCK, PMSF and aprotinin, which are typical serine protease inhibitors (5), showed no significant inhibitory effects on the enzyme activity (Table III). These results suggest that SVMP-MM is a typical metalloprotease requiring a certain metal ion as a co-factor for the enzymatic activity and not a serine protease. In addition, the enzyme activity was completely abolished by treatment with a reducing agent, such as DTT (Table III). This result suggests that a disulfide bond(s) located in the enzyme plays an important role in maintaining the enzyme activity. On the other hand, the enzyme kinetic parameters for SVMP-MM were also estimated using the fluorescence-quenching peptide as a substrate (Table IV). The $K_{\mathrm{M}}$ and $k_{\text {cat }}$ values for the enzyme were estimated to be $0.015 \mathrm{mM}$ and $0.031 \mathrm{sec}^{-1}$, respectively, when Abz-HTEKLVTSDnp- $\mathrm{NH}_{2}$ was used as a substrate (Table IV). The $k_{\text {cat }} / K_{\mathrm{M}}$ value 
Table IV. Kinetic parameters for the cleavage of a fluorogenic peptide substrate by SVMP-MM.

\begin{tabular}{llll}
\hline Substrate used & $K_{\mathrm{M}}(\mathrm{mM})^{\mathrm{a}}$ & $K_{\mathrm{cat}}\left(\mathrm{sec}^{-1}\right)^{\mathrm{a}}$ & $K_{\mathrm{cat}} / K_{\mathrm{M}}\left(\mathrm{mM}^{-1} \mathrm{sec}^{-1}\right)$ \\
\hline Abz-HTEKLVTS(Dnp)-NH & $0.015 \pm 0.009$ & $0.31 \pm 0.042$ & 20.67 \\
\hline
\end{tabular}

${ }^{\text {aD }}$ ata from six independent experiments were expressed as mean value \pm SD. Abz, $o$-aminobenzoic acid; Dnp, 2,4-dinitrophenyl; SD, standard deviation.
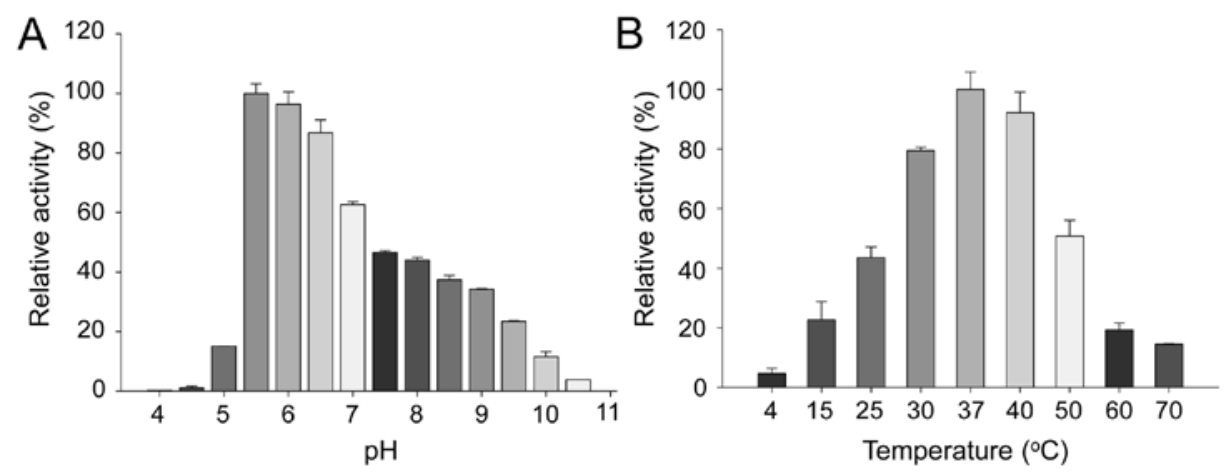

Figure 5. The $\mathrm{pH}$ - and temperature-dependency of snake venom metalloprotease (SVMP) enzyme from M. mauritanica snake venom (SVMP-MM). (A) Effect of $\mathrm{pH}$ on SVMP-MM activity. The enzyme ( $3 \mu \mathrm{g}$ ) was incubated with the fluorogenic peptide [80 $\mu \mathrm{M}$ of $o$-aminobenzoic acid (Abz)-HTEKLVTS-2,4-dinitrophenyl (Dnp)- $\mathrm{NH}_{2}$ in a final concentration] for $30 \mathrm{~min}$ at $37^{\circ} \mathrm{C}$ under different $\mathrm{pH}$ conditions as described in Materials and methods. (B) Effect of temperature on the enzyme activity. The same amount of enzyme was incubated with the same amount of fluorogenic peptide for 30 min at various temperatures as indicated in the standard reaction buffer $(\mathrm{pH} 5.5)$. The fluorescence produced was monitored for further $15 \mathrm{~min}$ at $\lambda_{\mathrm{em}}=420 \mathrm{~nm}$ and $\lambda_{\mathrm{ex}}=320 \mathrm{~nm}$. The level of fluorescence emitted was expressed as the reactive activity in percent, in which the fluorescence unit (RFU) values obtained in pH 5.5 and $37^{\circ} \mathrm{C}$ were regarded as $100 \%$.

of SVMP-MM was found to be $20.67 \mathrm{mM}^{-1} \mathrm{sec}^{-1}$, as well with the same fluorogenic substrate (Table IV).

Induction of vascular permeability and digestion of type IV collagen by SVMP-MM. In general, vascular permeability is a leakage of fluids and molecules from the blood stream to the extravascular space when the vascular basement membrane comprised of various protein components, such as laminin and type IV collagen is destroyed under a circumstance (38). This leakage can also be enhanced by effectors, such as inflammatory mediators and vascular endothelial growth factor (VEGF) (39). In this study, the activity of SVMP-MM related to the induction of vascular permeability was also observed in vivo (Fig. 6) using Miles assay as described in the Materials and methods, and as previously described $(8,25)$. As shown in Fig. 6A-C, PBS only did not evoke the leakage of Evans blue dye (Fig. 6A); however, SVMP-MM induced vascular permeability (Fig. 6B), during which approximately $8 \mu \mathrm{g}$ of dye leakage occurred following the injection of $10 \mu \mathrm{g}$ of SVMP-MM (Fig. C). In addition, the enzyme digested type IV collagen, which is a major component of the vascular basement membrane (Fig. 6D). These results suggest that the induction of vascular permeability may be related to the SVMP-MM activity capable of digesting some basal membranes and extracellular matrix proteins, such as type IV collagen $(32,39)$.

\section{Discussion}

In this study, a novel fibrin(ogen)olytic metalloprotease termed SVMP-MM from the M. mauritanica snake venom was purified and biochemically characterized in terms of enzyme kinetics and substrate specificity. The enzyme was purified homogeneously by three chromatographic steps, including one size exclusion and two sorts of anion exchangers in order (Fig. 1). The purified SVMP-MM is a monomeric protease and $27 \mathrm{kDa}$ in size, as judged by SDS-PAGE (Fig. 1D) and a gel filtration (data not shown). The size of SVMP-MM seems to be similar to that of several snake venom metalloproteases, such as BlaH1 (28 kDa) (26) and VIF (26 kDa) (27). In addition, the SVMP-MM has an amino acid stretch (that is N-QRFAPRYIEL-C) at its N-terminus, which shows high homology with those of metalloproteases, including BAP1 (28), lebetase-II, lebetase-4 and VIF $(16,17,27,31,40)$ (Table II).

SVMP-MM actively digested various plasma proteins, including fibrinogen, plasminogen, and prothrombin, which are participating in blood coagulation and hemostasis. However, the enzyme did not show any amidolytic activity towards typical chromogenic substrates for plasmin (S-2251) and for thrombin (Boc-VPR- $p \mathrm{NA}$ ). In addition, there was no occurrence of spontaneous polymerization of fibrin monomers, possibly produced from the fibrinogen cleavage by SVMP-MM, as judged by turbidity assay (Fig. 2B). These results demonstrate that the enzyme does not act as a plasminogen or prothrombin activator, as do other SVMPs from snake venom $(6,32,41)$.

It should be noted that the A $\alpha$-chain of fibrinogen was completely digested by the SVMP-MM protease for $20 \mathrm{~min}$, while the $B \beta$ - and the $\gamma$-chains remained intact for the same incubation time (Fig. 2A). As regards the B $\beta$-chain of fibrinogen, it was completely digested after $480 \mathrm{~min}$ of incubation. However, the $\gamma$-chain and the $\gamma-\gamma$ polymer of fibrin(ogen) 

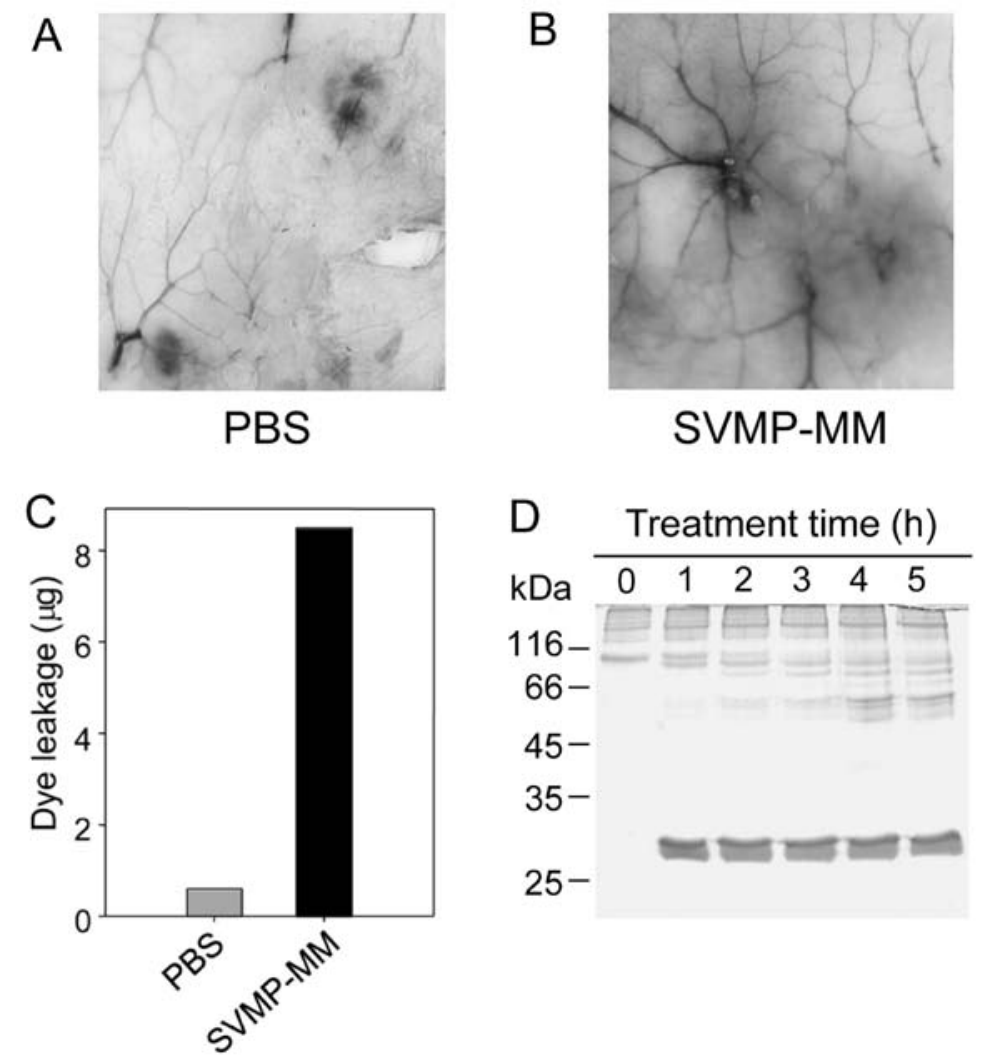

Figure 6. Induction of vascular permeability by snake venom metalloprotease (SVMP) enzyme from M. mauritanica snake venom (SVMP-MM) (A and B) Induction of vascular permeability by (A) phosphate-buffered saline (PBS) and (B) SVMP-MM. Evans dye was administered intravenously and then PBS or $10 \mu \mathrm{g}$ of SVMP-MM was injected intradermally as described in Materials and methods. After $10 \mathrm{~min}$, the animal was sacrificed and photographed. (C) Quantification of the dye leakage. To quantify the leakage of the dye, the back skin around the injection spot was cut out and then incubated in $3 \mathrm{ml}$ of formamide at $60^{\circ} \mathrm{C}$ for $48 \mathrm{~h}$. The dye exclusion was determined by measuring the absorbance at $620 \mathrm{~nm}$ and expressed as a measure in micrograms of Evans dye efflux. (D) Digestion of type IV collagen by SVMP-MM. Type IV collagen (total $32 \mu \mathrm{g}$ ) was incubated with $8 \mu \mathrm{g}$ of SVMP-MM in $200 \mu 1$ of the standard reaction buffer at $37^{\circ} \mathrm{C}$. At various time intervals as indicated, $30 \mu 1$ each of aliquots were withdrawn and mixed with $6 \mu 1$ of 6 X SDS-PAGE sample buffer. The samples were then boiled for $3 \mathrm{~min}$ and then the proteins were electrophoresed on $8 \%$ SDS-polyacrylamide gel, followed by staining the gel with Coomassie brilliant blue.

were not completed digested by the enzyme (Fig. 2A and D). A number of SVMPs, including fibrolase from Agkistrodon contortrix contortrix (A. contortrix contortrix) (42), atroxase from Crotalus atrox (C. atrox) (9) and lebetase from $M$. lebetina (43) preferentially cleave the A $\alpha$-chain and the $\mathrm{B} \beta$-chain of fibrinogen slowly, together with their digesting activities which favor towards the $\alpha-\alpha$ polymer of fibrin. However, they cannot cleave the $\gamma$-chain and the $\gamma-\gamma$ polymer of fibrin(ogen), apart from atrolysin $\mathrm{F}$ from C. atrox (9). Therefore, SVMP-MM seems to be a fibrin(ogen)ase belonging to snake venom metalloprotease family, which can digest both the $A \alpha$ and the $\mathrm{B} \beta$-chains of fibrinogen.

Azocasein assay is routinely used for examining the proteolytic activity of most proteases $(22,24)$. Unfortunately, SVMP-MM did not effectively cleave azocasein as a substrate. Therefore, the assay seemed not to be suitable for examining SVMP-MM activity. The enzyme also showed only a background level of amidolytic activity against various chromogenic substrates listed in the Materials and methods. This inability of the amidolytic activity of the enzyme towards the chromogenic substrates may be due to its ability to cleave the peptide bond only at the amino side (termed forward-amino acid cleaving activity), rather than at the carboxyl side of the peptide substrate. Since the chromogenic substrates used in this study are all coupled to $p$ NA groups at their carboxyl sides, an amino acid-tethered $p$ NA would be released by the enzyme action, which makes no measurable yellowish color change. For example, one protease of SVMPs from B. moojeni venom shows the forward-serine cleaving activity, accordingly the enzyme activity can be estimated only with a fluorescencequenching peptide substrate MCA-GXXPSXQED-Dnp (29). Thus, it was absolutely necessary to obtain a sensitive peptide substrate for SVMP-MM, which could be used for investigating the $\mathrm{pH}$ - and temperature-dependencies, the responsiveness to various protease inhibitors and salts, and the determination of kinetic parameters. One way to prepare a peptide substrate for SVMP-MM was to synthesize it on the basis of the cleavage site of enzyme. Since SVMP-MM specifially cleaved the K-L bond located in the $\alpha$-chain of fibrinogen substrate (Fig. 2A), an octameric fluorescence-quenching peptide containing the K-L cleavage site was synthesized, to which Abz (as a fluorescent donor) and Dnp (as a quencher) groups were attached at the $\mathrm{N}$ - and the C-termini, respectively $(36,44)$. The SVMP-MM activity was sensitively assayed with this fluorescencequenching peptide as a substrate by monitoring the increase in RFU at $\lambda_{\mathrm{ex}}=320 \mathrm{~nm}$ and $\lambda_{\mathrm{em}}=420 \mathrm{~nm}$ (Fig. 2B). The results 
revealed that the fluorescence-quenching peptide synthesized may be used for effectively testing the activity of SVMP-MM from crude venom.

SVMP-MM showed its maximum activity at $37^{\circ} \mathrm{C}$ and under pH 5.5 (Fig. 5). Although one type of SVMP, such as CcHaseII from Cerastes cerastes also shows the maximal activity at the same conditions (45), similar to SVMP-MM, the relative weak acidic $\mathrm{pH}$ requirement for the SVMP-MM activity seems to be a slightly different characteristic from other SVMPs that exhibit optimal activities, in general, under neutral or weak alkalic conditions $(16,47,48)$. The enzyme activity of SVMP-MM was greatly decreased at low temperatures (approximately $4^{\circ} \mathrm{C}$ ) (Fig. 5B). This cold sensitivity of the enzyme was not expected as the majority of SVMPs, such as CcHaseII (45) and BpirMP (46) are still active at this temperature. The enzyme activity of SVMP-MM was inhibited by $\mathrm{Zn}^{2+}$ at $1 \mathrm{mM}$, and did not show significance at a low dose (Table III). This property is in accordance with those of some metalloproteases that contain $\mathrm{Zn}^{2+}$ in their catalytic centers (30). The enzyme activity of SVMP-MM was completedly inhibited by a reducing agent DTT (Table III), demonstrating that a disulfide bond(s) located in the enzyme may play an important role in maintaining the enzyme activity. A number of SVMPs, including BAP1, lebetases, BmooMP $\alpha-\mathrm{I}$, and neuwiedase are also completely inhibited by DTT (30).

SVMPs are classified as P-I, P-II and P-III classes, depending on their size and domain structure differences (30). P-I proteases are small SVMPs in size (molecular masses of 20-30 kDa) and contain only a pro and a catalytic domain. P-II SVMPs are medium-sized enzymes (30-60 kDa) and are composed of pro, catalytic and disintegrin domains. P-IIIs are large enzymes $(60-100 \mathrm{kDa})$ and contain pro, catalytic, disintegrin-like and cysteine-rich domains $(29,30)$. A recent study on the crystal structures of P-I class SVMPs have demonstrated that SVMPs have a consensus HEXXHXXGXXHD sequence and a Met-turn structure that contains a conserved Met residue forming a hydrophobic basement for the three zinc-binding histidine residues in the consensus sequence (30). By these criteria, SVMP-MM can be categorized as a P-I class enzyme, as its molecular mass is $27 \mathrm{kDa}$ composed of a single polypeptide (Fig. 1D) and its activity is completely inhibited by typical metalloprotease inhibitors, such as 1,10-PT and EGTA (Table III). However, further studies are required to reveal the domain structure of SVMP-MM and whether the enzyme has a catalytic domain containing a consensus $\mathrm{Zn}^{2+}$ binding motif and Met-turn structure, even though it has a high homology amino acid stretch at its N-terminus with those of typical P-I enzymes (Table II).

On the other hand, SVMP-MM has two typical activities: i) to induce a vascular permeability, as judged by Miles assay (Fig. 6B and C); and ii) to cleave type IV collagen (Fig. 6D), one of the basal membrane and extracellular matrix proteins, together with other proteins, such as fibronectin and laminin (32). Moreover, it also hydrolyzes plasma proteins, such as prothrombin, plasminogen, fibrinogen and XL-fibrin, which are involved in blood coagulation and hemostasis. Therefore, the ability of SVMP-MM to induce vascular permeability and degrade the plasma proteins and type IV collagen may likely be related to the disturbance of blood hemostasis by the enzyme. However, it cannot be ruled out that SVMP-MM can induce vascular permeability by activating mast cells to release mediators, such as histamine, which provoke a rapid increase in plasma extravasation in animal skin (49). To verify the direct induction ability of SVMP-MM, further studies related to the activation of mast cells and the release of cellular mediators, such as histamine are required.

Taken together, the data from present study demonstrate that: i) SVMP-MM is a metalloprotease which is small in size (27 kDa molecular mass) from M. mauritanica snake venom(Fig. 1D); ii) it can cleave fibrinogen and XL-fibrin (Fig. 2) without having prothrombin- and prothrombin-activating abilities (data not shown); iii) it is very sensitive to divalent cation chelators, such as EDTA and EGTA and a reducing agent, such as DTT (Table III); iv) it can be inhibited by a typical metalloprotease inhibitor, such as 1,10-PT (Table III); v) it has a high sequence identity at its N-terminus to those of typical P-I SVMPs (Table II); and vi) it can induce vascular permeability by digesting type IV collagen (Fig. 6). In conclusion, these results demonstrate that SVMP-MM is a fibrin(ogen)olytic metalloprotease of the P-I class, which can induce a hemorrhagic reaction in vivo.

\section{Acknowledgements}

This study was supported by a research fund from Chosun University, 2013.

\section{References}

1. Gutiérrez JM, Escalante T and Rucavado A: Experimental pathophysiology of systemic alterations induced by Bothrops asper snake venom. Toxicon 54: 976-987, 2009.

2. Rucavado A, Soto M, Escalante T, Loria GD, Arni R and Gutiérrez JM: Thrombocytopenia and platelet hypoaggregation induced by Bothrops asper snake venom. Toxins involved and their contribution to metalloproteinase-induced pulmonary hemorrhage. Thromb Haemost 94: 123-131, 2005.

3. Takeda S, Takeya H and Iwanaga S: Snake venom metalloproteinases: Structure, function and relevance to the mammalian ADAM/ADAMTS family proteins. Biochim Biophys Acta 1824: 164-176, 2012.

4. White J: Snake venoms and coagulopathy. Toxicon 45: 951-967, 2005.

5. Matsui T, Fujimura Y and Titani K: Snake venom proteases affecting hemostasis and thrombosis. Biochim Biophys Acta 1477: 146-156, 2000.

6. Markland FS Jr and Swenson S: Snake venom metalloproteinases. Toxicon 62: 3-18, 2013.

7. Anderson SG and Ownby CL: Systemic hemorrhage induced by proteinase $\mathrm{H}$ from Crotalus adamanteus (eastern diamondback rattlesnake) venom. Toxicon 35: 1301-1313, 1997.

8. Nagy JA, Benjamin L, Zeng H, Dvorak AM and Dvorak HF: Vascular permeability, vascular hyperpermeability and angiogenesis. Angiogenesis 11: 109-119, 2008.

9. Tu AT, Baker B, Wongvibulsin S and Willis T: Biochemical characterization of atroxase and nucleotide sequence encoding the fibrinolytic enzyme. Toxicon 34: 1295-1300, 1996.

10. Berger M, Pinto AF and Guimarães JA: Purification and functional characterization of bothrojaractivase, a prothrombinactivating metalloproteinase isolated from Bothrops jararaca snake venom. Toxicon 51: 488-501, 2008.

11. Kress LF and Catanese J: Enzymatic inactivation of human antithrombin III. Limited proteolysis of the inhibitor by snake venom proteinases in the presence of heparin. Biochim Biophys Acta 615: 178-186, 1980.

12. Garrigues T, Dauga C, Ferquel E, Choumet V and Failloux A-B: Molecular phylogeny of Vipera Laurenti, 1768 and the related genera Macrovipera (Reuss, 1927) and Daboia (Gray, 1842), with comments about neurotoxic Vipera aspis aspis populations. Mol Phylogenet Evol 35: 35-47, 2005. 
13. Lago NR, de Adolfo Roodt R, Archundia I, et al: Local damage produced by Vipera and Macrovipera venoms and some immunochemical characteristics. Toxicon 60: 227, 2012.

14. Archundia IG, de Roodt AR, Ramos-Cerrillo B, et al: Neutralization of Vipera and Macrovipera venoms by two experimental polyvalent antisera: A study of paraspecificity. Toxicon 57: 1049-1056, 2011.

15. Samel M, Subbi J, Siigur J and Siigur E: Biochemical characterization of fibrinogenolytic serine proteinases from Vipera lebetina snake venom. Toxicon 40: 51-54, 2002.

16. Siigur J, Samel M, Tõnismägi K, Subbi J, Siigur E and Tu AT: Biochemical characterization of lebetase, a direct-acting fibrinolytic enzyme from Vipera lebetina snake venom. Thromb Res 90: 39-49, 1998

17. Trummal K, Vija H, Subbi J and Siigur J: MALDI-TOF mass spectrometry analysis of substrate specificity of lebetase, a direct-acting fibrinolytic metalloproteinase from Vipera lebetina snake venom. Biochim Biophys Acta 1476: 331-336, 2000.

18. Swenson S and Markland FS Jr: Snake venom fibrin(ogen)olytic enzymes. Toxicon 45: 1021-1039, 2005.

19. Leonardi A, Fox JW, Trampus-Bakija A and Krizaj I: Ammodytase, a metalloprotease from Vipera ammodytes venom, possesses strong fibrinolytic activity. Toxicon 49: 833-842, 2007.

20. Markland FS Jr: Snake venom fibrinogenolytic and fibrinolytic enzymes: an updated inventory. Registry of Exogenous Hemostatic Factors of the Scientific and Standardization Committee of the International Society on Thrombosis and Haemostasis. Thromb Haemost 79: 668-674, 1998.

21. Buschek S, Ignjatovic V, Summerhayes R and Lowe R: The effect of different snake venoms and anti-venoms on thrombin clotting time in human plasma. Thromb Res 125: e149-e152, 2010.

22. Park JW, Park JE, Choi HK, Jung TW, Yoon SM and Lee JS: Purification and characterization of three thermostable alkaline fibrinolytic serine proteases from the polychaete Cirriformia tentaculata. Process Biochem 48: 979-987, 2013.

23. Laemmli UK: Cleavage of structural proteins during the assembly of the head of bacteriophage $\mathrm{T}_{4}$. Nature 227: 680-685, 1970.

24. Chang AK, Kim HY, Park JE, et al: Vibrio vulnificus secretes a broad-specificity metalloprotease capable of interfering with blood homeostasis through prothrombin activation and fibrinolysis. J Bacteriol 187: 6909-6916, 2005.

25. Miles AA and Miles EM: Vascular reactions to histamine, histamine-liberator and leukotaxine in the skin of guinea-pigs. J Physiol 118: 228-257, 1952.

26. Stroka A, Donato JL, Bon C, Hyslop S and de Araújo AL: Purification and characterization of a hemorrhagic metalloproteinase from Bothrops lanceolatus (Fer-de-lance) snake venom. Toxicon 45: 411-420, 2005.

27. Gasmi A, Srairi N, Karoui H and El Ayeb M: Amino acid sequence of VlF: identification in the C-terminal domain of residues common to non-hemorrhagic metalloproteinases from snake venoms. Biochim Biophys Acta 1481: 209-212, 2000.

28. Watanabe L, Shannon JD, Valente RH, et al: Amino acid sequence and crystal structure of $\mathrm{BaP} 1$, a metalloproteinase from Bothrops asper snake venom that exerts multiple tissuedamaging activities. Protein Sci 12: 2273-2281, 2003.

29. Okamoto DN, Kondo MY, Oliveira LC, et al: P-I class metalloproteinase from Bothrops moojeni venom is a post-proline cleaving peptidase with kininogenase activity: Insights into substrate selectivity and kinetic behavior. Biochim Biophys Acta 1844: 545-552, 2014.

30. Rodrigues VM, Soares AM, Guerra-Sá R, Rogrigues V, Fontes MR and Giglio JR: Structural and functional characterization of neuwiedase, a nonhemorrhagic fibrin(ogen)olytic. Arch Biochem Biophys 38: 213-224, 2000.

31. Siigur E, Aaspõllu A, Tu AT and Siigur J: cDNA cloning and deduced amino acid sequence of fibrinolytic enzyme (lebetase) from Vipera lebetina snake venom. Biochem Biophys Res Commun 224: 229-236, 1996.
32. Sajevic T, Leonardi A, Kovačič L, et al: VaH3, one of the principal hemorrhagins in Vipera ammodytes ammodytes venom, is a homodimeric P-IIIc metalloproteinase. Biochimie 95: 1158-1170, 2013

33. Huang KF, Hung CC, Pan FM, Chow LP, Tsugita A and Chiou SH: Characterization of multiple metalloproteinases with fibrinogenolytic activity from the venom of Taiwan habu (Trimeresurus mucrosquamatus): protein microsequencing coupled with cDNA sequence analysis. Biochem Biophys Res Commun 216: 223-233, 1995.

34. Xiao R, Li QW, Perrett S and He RQ: Characterisation of the fibrinogenolytic properties of the buccal gland secretion from Lampetra japonica. Biochimie 89: 383-392, 2007.

35. Doolittle RF, Watt KWK, Cottrell BA, Strong DD and Riley M: The amino acid sequence of the alpha-chain of human fibrinogen. Nature 280: 464-468, 1979.

36. Araujo MC, Melo RL, Cesari MH, Juliano MA, Juliano L and Carmona AK: Peptidase specificity characterization of C- and $\mathrm{N}$-terminal catalytic sites of angiotensin I-converting enzyme. Biochemistry 39: 8519-8525, 2000.

37. Baker AH, Edwards DR and Murphy G: Metalloproteinase inhibitors: biological actions and therapeutic opportunities. J Cell Sci 115: 3719-3727, 2002.

38. Norris LA: Blood coagulation. Best Pract Res Clin Obstet Gynaecol 17: 369-383, 2003.

39. Yamazaki Y, Nakano Y, Imamura T and Morita T: Augmentation of vascular permeability of VEGF is enhanced by KDR-binding proteins. Biochem Biophys Res Commun 355: 693-699, 2007.

40. Gasmi A, Srairi N, Guermazi S, Dekhil H, Karoui H and El Ayeb M: Amino acid structure and characterization of a heterodimeric disintegrin from Vipera lebetina venom. Biochim Biophys Acta 1547: 51-56, 2001.

41. Pereira AL, Fritzen M, Faria F, Motta G and ChudzinskiTavassi AM: Releasing or expression modulating mediator involved in hemostasis by Berythractivase and Jararhagin (SVMPs). Toxicon 47: 788-796, 2006.

42. Randolph A, Chamberlain SH, Chu HL, Retzios AD, Markland FS Jr and Masiarz FR: Amino acid sequence of fibrolase, a direct-acting fibrinolytic enzyme from Agkistrodon contortrix contortrix venom. Protein Sci 1: 590-600, 1992.

43. Aaspõllu A, Siigur J and Siigur E: cDNA cloning of a novel P-I lebetase isoform Le-4. Toxicon 46: 591-594, 2005.

44. Oyama E, Kitagawa Y and Takahashi H: Primary structure and characterization of a non hemorrhagic metalloproteinase with fibrinolytic activity, from the snake venom of Protobothrops tokarensis (Tokara-habu). Toxicon 70: 153-161, 2013.

45. Wahby AF, Mahdy el SM, El-Mezayen HA, Salama WH, Abdel-Aty AM and Fahmy AS: Egyptian horned viper Cerastes cerastes venom hyaluronidase: purification, partial characterization and evidence for its action as a spreading factor. Toxicon 60: 1380-1389, 2012.

46. Bernardes CP, Menaldo DL, Camacho E, et al: Proteomic analysis of Bothrops pirajai snake venom and characterization of BpirMP a new P-I metalloproteinase. J Proteomics 80: 250-267, 2013.

47. Bernardes CP, Santos-Filho NA, Costa TR, et al: Isolation and structural characterization of a new fibrin(ogen)olytic metalloproteinase from Bothrops moojeni snake venom. Toxicon 51: 574-584, 2008.

48. Sun MZ, Liu S and Greenaway FT: Characterization of a fibrinolytic enzyme (ussurenase) from Agkistrodon blomhoffii ussurensis snake venom: insights into the effects of $\mathrm{Ca}^{2+}$ on function and structure. Biochim Biophys Acta 1764: 1340-1348, 2006.

49. Rubinstein I, Nadel JA, Graf PD and Caughey GH: Mast cell chymase potentiates histamine-induced wheal formation in the skin of ragweed-allergic dogs. J Clin Invest 86: 555-559, 1990. 